\title{
Pengembangan Alat Peraga Kotak Mitigasi Bencana sebagai Penunjang Pembelajaran Kebencanaan di Sekolah Dasar
}

\author{
Syahrial $\mathrm{A}^{\mathbf{1}^{*}}$, I Nyoman Sri Putu Verawati ${ }^{2}$, Jannatin Ardhuha ${ }^{3}$, Muhammad Zuhdi ${ }^{4}$ \\ 1) 2) 3) 4) Program Studi Pendidikan Fisika, PMIPA, Universitas Mataram, Jl. Majapahit 62 \\ Mataram, Indonesia 83125 \\ Email: syahrial_ayub@unram.ac.id
}

\begin{tabular}{|c|c|}
\hline Article Info & Bstract \\
\hline $\begin{array}{l}\text { Article History } \\
\text { Received: } 26 \text { March } 2020 \\
\text { Revised: } 30 \text { April } 2020 \\
\text { Published: } 15 \text { June } 2020\end{array}$ & \multirow{2}{*}{$\begin{array}{l}\text { The purpose of this research is to develop a tool for disaster mitigation box as } \\
\text { a support for learning disaster in elementary schools. This research uses the } \\
R \& D \text { approach according to Borg \& Gall, which includes the step of } \\
\text { development, pilot testing, and the final testing. In The development stage, } \\
\text { resulted in seven aspects of the mitigation box namely a disaster poster, } \\
\text { disaster impact poster, evacuation map, symbols for evacuation, newspaper } \\
\text { clippings, disaster stories and songs about disasters. The seven aspects are } \\
\text { declared very feasible to use in disaster learning. The trial phase is a limited } \\
\text { trial. Limited trials were carried out } 2 \text { times to } 32 \text { students in grade III of SD } \\
\text { Negeri } 6 \text { Mataram. In this limited trial it was stated that this disaster } \\
\text { mitigation box was very suitable for learning. Disaster mitigation box testing } \\
\text { phase is the stage to determine the effect of the use of disaster mitigation boxes } \\
\text { to increase disaster awareness. Increased disaster awareness is determined } \\
\text { based on the gain score. The results of the study concluded that the gain score } \\
\text { for implementing the disaster mitigation box was 0.50 (medium). The } \\
\text { development of the disaster mitigation box teaching aid received a good } \\
\text { response from students by } 80.80 \% \text { and according to observers the learning } \\
\text { went very well. The results of the research and validation test of learning } \\
\text { development experts using disaster mitigation box props are worthy to be used } \\
\text { as references in disaster learning. }\end{array}$} \\
\hline $\begin{array}{l}\text { Keywords } \\
\text { teaching aids, disaster } \\
\text { mitigation boxes, learning, } \\
\text { elementary school }\end{array}$ & \\
\hline Informasi Artikel & Abstrak \\
\hline $\begin{array}{l}\text { Sejarah Artikel } \\
\text { Diterima: } 26 \text { Maret } 2020 \\
\text { Direvisi: } 30 \text { April } 2020 \\
\text { Dipublikasi: 15 Juni } 2020\end{array}$ & \multirow{2}{*}{$\begin{array}{l}\text { Tujuan penelitian ini adalah mengembangkan alat peraga kotak mitigasi } \\
\text { bencana sebagai penunjang pembelajaran kebencanaan di sekolah dasar. } \\
\text { Penelitian ini menggunakan pendekatan } R \text { \& } D \text { menurut Borg \& Gall, yang } \\
\text { meliputi tahap pengembangan, uji coba, dan pengujian. Tahap pengembangan } \\
\text { dihasilkan tujuh aspek kotak mitigasi yaitu poster bencana, poster dampak } \\
\text { bencana, peta evakuasi, simbol-simbol untuk evakuasi, kliping koran, cerita } \\
\text { bencana dan lagu tentang bencana. Ketujuh aspek tersebut dinyatakan sangat } \\
\text { layak digunakan dalam pembelajaran kebencanaan. Tahap uji coba dilakukan } \\
\text { uji coba terbatas. Uji coba terbatas dilakukan sebanyak } 2 \text { kali kepada } 32 \text { siswa } \\
\text { kelas III SD Negeri } 6 \text { Mataram. Pada uji coba terbatas ini dinyatakan kotak } \\
\text { mitigasi bencana ini sangat layak digunakan untuk pembelajaran. Tahap } \\
\text { pengujian kotak mitigasi bencana adalah tahap untuk mengetahui pengaruh } \\
\text { penggunaan kotak mitigasi bencana terhadap peningkatan kesadaran bencana. } \\
\text { Peningkatan kesadaran bencana ditentukan berdasarkan gain score. Hasil } \\
\text { penelitian disimpulkan bahwa gain score penerapan kotak mitigasi bencana } \\
\text { adalah 0,44 (sedang). Pengembangan alat peraga kotak mitigasi bencana } \\
\text { mendapat respon yang baik dari siswa sebesar } 79,51 \text { \% dan menurut pengamat } \\
\text { pembelajaran telah berjalan dengan sangat baik. Hasil penelitian dan uji } \\
\text { validasi ahli pengembangan pembelajaran dengan alat peraga kotak mitigasi } \\
\text { bencana layak untuk dijadikan referensi dalam pembelajaran kebencanaan. }\end{array}$} \\
\hline $\begin{array}{l}\text { Kata kunci } \\
\text { alat peraga, kotak mitigasi } \\
\text { bencana, pembelajaran, } \\
\text { sekolah dasar }\end{array}$ & \\
\hline & \\
\hline
\end{tabular}




\section{PENDAHULUAN}

Hasil penelitian awal yang dilakukan oleh Syahrial (2019) kepada guru guru SD Negeri 6 Mataram menunjukkan bahwa dalam pembelajaran yang dilakukan, guru lebih memilih metode ceramah dibandingkan metode metode yang menggunakan alat peraga. Berbagai alasan guru memilih metode ceramah adalah: (1) sekolah tidak mempunyai alat peraga kebencanaan, (2) tidak ada ruang laboratorium yang dapat digunakan untuk menerapkan alat peraga, (3) pembelajaran dengan menggunakan alat peraga memerlukan waktu pembelajaran yang lama, (4) tidak mempunyai laboran untuk mempersiapkan peralatan untuk praktek, dan (5) guru kesulitan membuat lembar kerja untuk siswa.

Berdasarkan hasil penelitian ini tentu sangat disayangkan, karena potensi guru dan sekolah kurang dimaksimalkan untuk meningkatkan kesadaran bencana pada siswa. Pembelajaran dengan ceramah tentu saja kurang memberikan pengalaman kepada siswa untuk menunjukkan fakta dari sebuah teori. Pengalaman dari fakta sebuah teori dapat diperoleh jika pembelajaran menggunakan model inkuiri. Berdasarkan aktifitas siswa, menurut Jufri (2013) pembelajaran berbasis inkuiri dibagi menjadi 3 macam, yaitu 1) inkuiri terstruktur yaitu peserta didik mengikuti dengan tepat instruksi dari pendidik untuk menyelesaikan kegiatan hands-on dengan sempurna, 2) inkuiri terbimbing yaitu peserta didik mengembangkan cara kerja untuk mencari jawaban dari pertanyaan yang dipilih, 3) inkuiri bebas, yaitu peserta didik menurunkan pertanyaan tentang topik yang dipilih pendidik dan merencanakan sendiri penyelidikannya. Sarwi \& Khanafiyah (2010) menyatakan inkuiri terbimbing untuk guru berhubungan dengan peran guru mengajukan permasalahan dan diikuti siswa dalam menentukan proses dan penyelesaian masalah. Pengalaman dari fakta sebuah teori dapat diperoleh jika pembelajaran berorientasi pada siswa dan praktek menggunakan alat peraga. Mempertimbangkan bahwa siswa belum terbiasa melakukan kegiatan sendiri, maka pada penelitian ini perlu bimbingan dari guru. Kholifudin (2012), siswa yang belajar dengan terbimbing melalui eksperimen memperoleh prestasi yang lebih baik dari pada siswa yang belajar dengan demontrasi. Wulandari (2014) lebih lanjut menyatakan bahwa hasil belajar siswa yang menerapkan pembelajaran terbimbing lebih tinggi dari pada siswa yang belajar dengan menggunakan metode ceramah. Pendapat di atas menegaskan bahwa pembelajaran terbimbing dapat memperoleh hasil belajar yang lebih baik dibandingkan dengan ceramah. Guru yang menggunakan ceramah dalam pembelajaran secara tidak langsung guru kurang dapat menggali potensi siswa secara maksimal. Pembelajaran yang dilakukan dengan cara seperti ini membosankan, sehingga siswa beranggapan bahwa pembelajaran itu sulit dan tidak menarik. Pendapat di atas sejalan dengan Astra (2012) menyatakan bahwa pelajaran dengan metode ceramah merupakan pelajaran yang sulit dan tidak disenangi siswa.

Menanamkan kesadaran bencana pada siswa merupakan suatu proses (Syahrial, 2019). Kesadaran bencana tidak mungkin muncul begitu saja tanpa kegiatan yang tepat untuk menanamkannya. Sekolah merupakan salah satu tempat yang dapat digunakan untuk menanamkan kesadaran bencana kepada siswa. Kegiatan pembelajaran yang dilakukan sebaiknya menggunakan alat peraga, sehingga mampu membuat siswa senang mengikuti pembelajarannya. Sesuai dengan pendapat di atas proses pembelajaran yang menggunakan alat peraga diyakini akan lebih baik. Syahrial (2019), menemukan pembelajaran dengan mengunakan kit ipa memberikan motivasi dan meningkatkan kemampuan proses siswa. Sebaiknya permasalahan di atas menjadi sebuah sarana introspeksi bagi guru. Instropeksi untuk mencari dengan tepat model, metode dan media yang digunakan dalam pembelajaran (Djamarah, 2005). Salah satu upaya untuk membuat pembelajaran yang mampu menanamkan kesadaran bencana pada siswa adalah dengan membuat sebuah media pembelajaran berupa kotak mitigasi bencana. Pengetahuan kebencanaan sangat perlu diberikan kepada siswa (Disaptono S, 2005). Siswa harus memiliki pengetahuan dan keterampilan tentang kebencanaan. Bencana bisa datang tiba-tiba seperti saat bekerja, tidur, bermain, dan bahkan 
juga saat belajar di sekolah (Ivers,2002). Makanya siswa harus punya kesiapsiagaan dan mitigasi bencana. Pada penelitian ini dikembangkan 5 aspek kebencanaan yang diduga akan mampu menanamkan kesadaran bencana pada siswa. Lima aspek kebencanaan akan diberikan secara bertahap dan sistematis kepada siswa. Penelitian ini juga mengembangkan kotak mitigasi yang berisi alat peraga untuk pembelajaran kelima aspek ini. Lima aspek ini adalah pengetahuan kebencanaan (PK), tanda-tanda akan terjadi bencana (TB), dampak resiko dan upaya mengurangi (DR), kesiapsiagaan $(\mathrm{KN})$, dan prosedur, alat pertolongan pertama pada korban (AP). Penelitian ini juga didukung oleh buku penunjang yang dikembangkan dan ditulis oleh tim peneliti. Buku ini digunakan untuk mendukung pembelajaran kebencanaan yang dilakukan oleh peneliti.

\section{METODE}

Penelitian ini termasuk penelitian pengembangan yang menggunakan metode research and development $(R \& D)$. Produk yang dikembangkan dalam penelitian ini berupa alat peraga kotak mitigasi bencana yang digunakan pada pembelajaran kebencanaan di sekolah dasar. Research and development $(R \& D)$ pada penelitian ini dikembangkan sesuai pendapat Borg \& Gall dalam Sutopo (2009) yang terdiri dari sepuluh tahap seperti pada gambar 1.

Penelitian dilakukan di kelas V SD Negeri 6 Mataram. Sampel ditentukan dengan teknik cluster random sampling. Berdasarkan ini didapat sampel kelas V.A dan V.B yang mempunyai rata-rata kelas yang sama. Berdasarkan undian diperoleh kelas V.B sebagai kelas ujicoba dengan alat peraga kotak mitigasi bencana.

Data penelitian ini adalah data validasi ahli dan data kesadaran bencana. Sebelum digunakan untuk uji operasional, kotak mitigasi bencana dan instrumen pendukungnya (RPP dan LKPD) serta instrumen penelitian (instrumen kesadaran bencana, instrumen respon siswa, dan lembar observasi) divalidasi oleh 3 dosen ahli. Instrumen kesadaran bencana sebelum digunakan pada uji operasional, dilakukan ujicoba terbatas pada 33 siswa kelas VI SD Negeri 6 Mataram. Uji coba terbatas digunakan untuk menentukan validitas, reliabilitas, tingkat kesukaran dan daya beda soal kesadaran bencana.

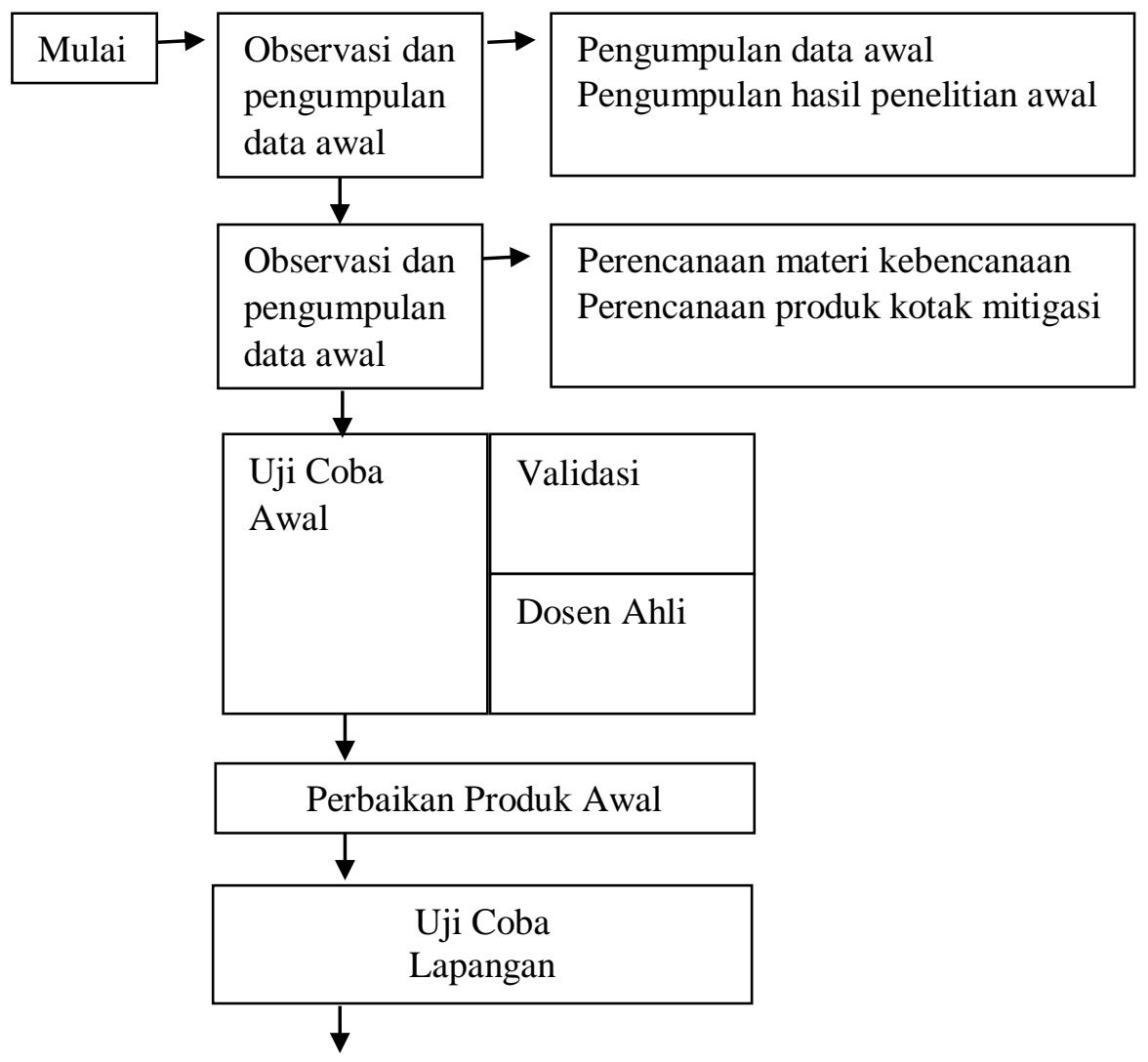




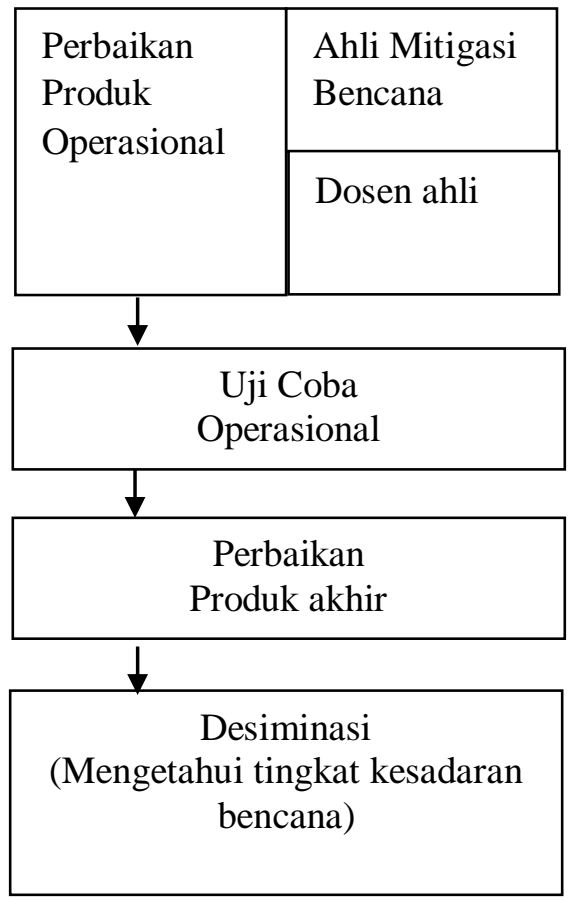

Gambar 1 : Tahapan Penelitian

Tes awal dilakukan sebelum kegiatan pembelajaran kebencanaan, sedangkan tes akhir diberikan setelah pembelajaran berakhir. Menurut Hake dalam Evawani, et al. (2015), nilai Gain dihitung dengan persamaan:

$$
<g>=\frac{S_{\text {post }-} S_{\text {pre }}}{S_{\text {maks }} S_{\text {pre }}}
$$

Dimana, $<g>$ adalah skor Gain, $S_{\text {post }}$ adalah skor tes akhir $S_{\text {pre }}$ adalah skor tes awal dan $S_{\text {maks }}$ adalah akor maksimal.

Tabel 1: Kriteria Skor Gain

\begin{tabular}{cc}
\hline Klasifikasi Skor Gain & Kategori \\
\hline $0,7<\langle g\rangle \leq 1$ & Tinggi \\
\hline $0,3<\langle g\rangle \leq 0,7$ & Sedang \\
\hline$\langle g\rangle \leq 0,3$ & Rendah \\
\hline
\end{tabular}

\section{HASIL DAN PEMBAHASAN}

\section{Kotak Mitigasi Bencana}

Penelitian ini menghasilkan alat beraga kotak mitigasi bencana. Kotak mitigasi bencana berisi 1) buku bencana alam gempabumi, tsunami, tanah longsor dan banjir, 2) aspek kesadaran bencana yang berisi pengetahuan kebencanaan (PK), tanda-tanda bencana (TB), dampak resiko dan upaya mengurangi $(\mathrm{DR})$, kesiapsiagaan $(\mathrm{KN})$, dan prosedur dan alat pertolongan pertama pada korban (AP). 


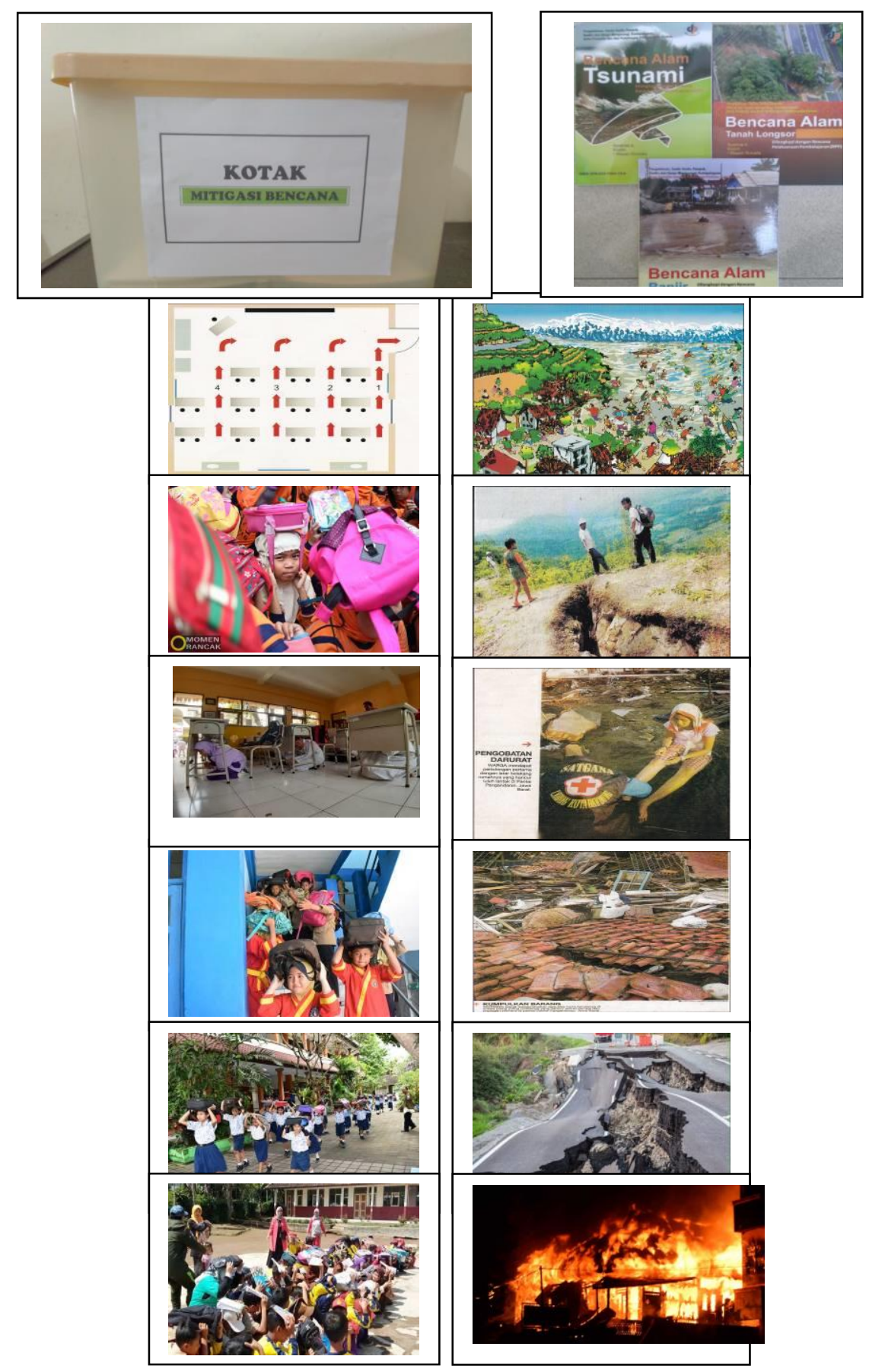

Gambar 2 : Kotak Mitigasi Bencana

\section{Hasil Validasi Ahli}

Hasil validasi dari ahli mitigasi bencana dan dosen ahli menggunakan penilaian skala 4, terhadap alat peraga kotak mitigasi bencana berdasarkan kualitas gambar, kualitas isi dan tujuan, kualitas pembelajaran, diperoleh rata-rata skor 3,56 dengan kategori sangat layak digunakan. Kriteria sangat layak digunakan juga diperoleh untuk RPP dan LKPD yang masing masing mendapatkan skor 3,75 dan 3,82. Sehingga secara keseluruhan dapat dinyatakan alat peraga kotak mitigasi bencana dan perangkat lainnya sangat layak digunakan untuk pembelajaran kebencanaan. 


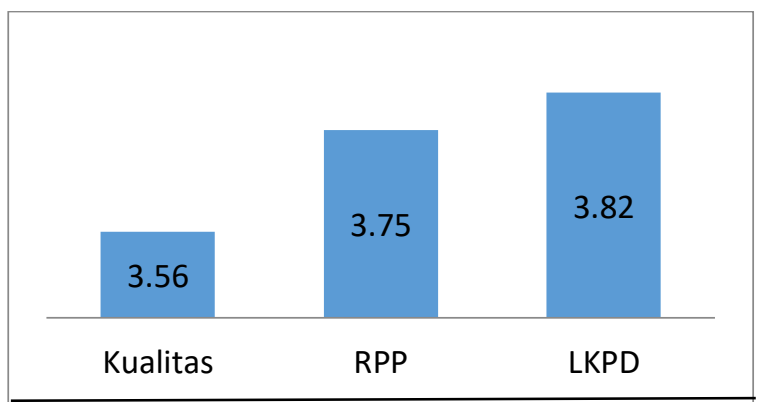

Gambar 3 : Hasil Validasi Kotak Mitigasi Bencana

\section{Hasil Belajar Kesadaran Bencana}

Syahrial (2019), mengungkapkan kesadaran bencana pada penelitian ini, meliputi pengetahuan kebencanaan (PK), tanda-tanda bencana (TB), dampak resiko dan upaya mengurangi (DR), kesiapsiagaan (KN), dan prosedur, alat pertolongan pertama pada korban (AP). Soal tes awal mencakup ke 5 pengetahuan dan keterampilan kesadaran bencana yang sudah diuraikan di atas. Soal yang telah memenuhi persyaratan digunakan untuk mengukur kemampuan awal siswa. Setelah dilakukan tes awal, maka selanjutnya dilakukan pembelajaran menggunakan alat peraga kotak mitigasi bencana sebanyak 5 kali pertemuan. Ke lima pertemuan itu adalah 1) PK, 2) TB, 3) DR, 4) KS, dan 5) AP. Tes akhir dilakukan pada pertemuan keenam dengan menggunakan soal tes awas yang sudah diperbaiki. Hasil tes awal dan tes akhir ditampilkan pada gambar 2 berikut :

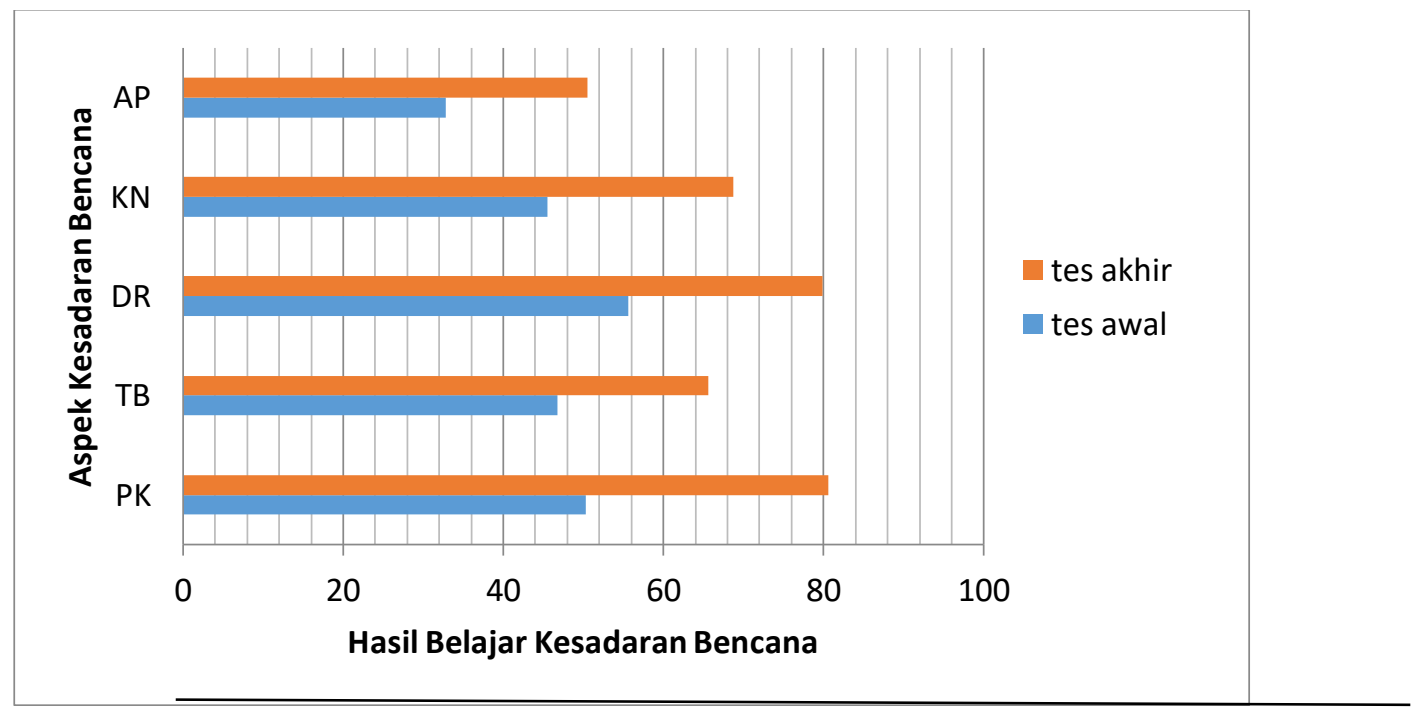

Gambar 4 : Grafik Tes Awal dan Tes Akhir Hasil Belajar Kesadaran Bencana

Data tes awal dan tes akhir yang digunakan untuk menghitung Gain Score pada tabel 1 berikut ini :

Tabel 2 : Data Gain Score masing masing Aspek Kesadaran Bencana

\begin{tabular}{ccccc}
\hline AKB & Tes Awal & Tes Akhir & Gain Score & Kriteria \\
\hline PK & 50,25 & 80,61 & 0,61 & sedang \\
\hline TB & 46,78 & 65,63 & 0,35 & sedang \\
\hline DR & 55,64 & 79,85 & 0,55 & sedang \\
\hline KN & 45,52 & 68,76 & 0,43 & sedang \\
\hline AP & 32,76 & 50,52 & 0,26 & Rendah \\
\hline
\end{tabular}


Tabel 2 menjadi indikator bahwa alat peraga kotak mitigasi bencana dapat digunakan untuk pembelajaran kebencanaan di sekolah dasar. Gain Score hasil belajar kesadaran bencana ditampilkan pada gambar 3 berikut.

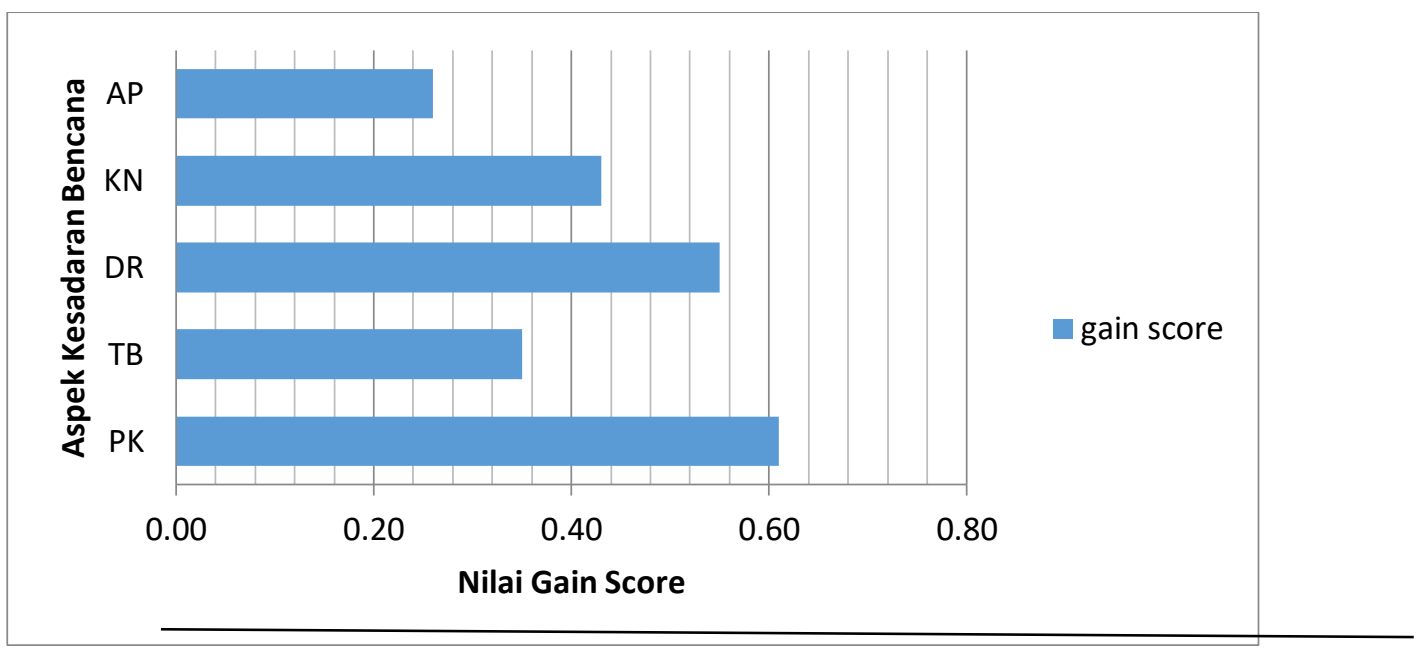

Gambar 5 : Grafik Gain Score Hasil Belajar Kesadaran Bencana

\section{Hasil Respon Siswa}

Respon siswa terhadap pembelajaran dengan alat peraga kotak mitigasi bencana adalah $83,5 \%$ siswa menyatakan senang, $73,6 \%$ siswa menyatakan mudah memahami dan $81,43 \%$ menyatakan bermanfaat.

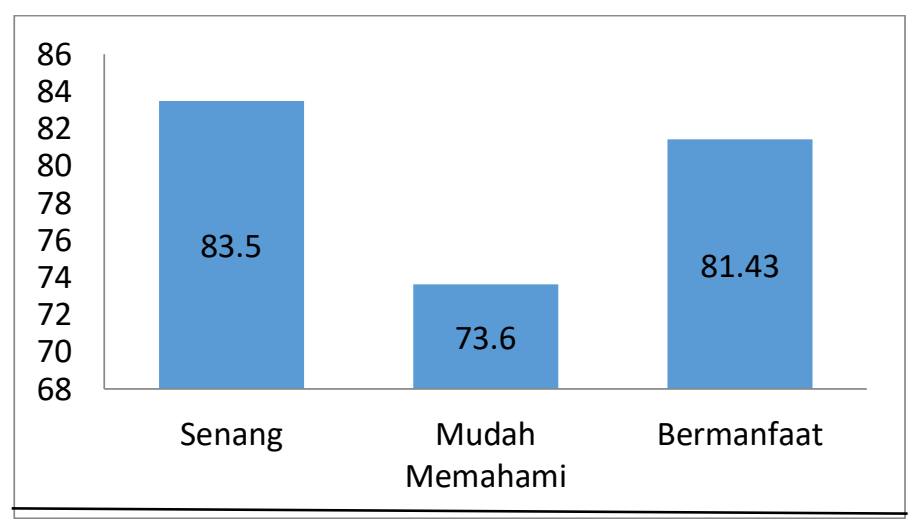

Gambar 6 : Respon Siswa Terhadap Pembelajaran dengan Kotak Mitigasi Bencana

\section{Hasil Penilaian Observer}

Penilaian terhadap proses pembelajaran yang dilakukan oleh pengamat memperoleh hasil, aspek 1) persiapan pembelajaran memperoleh skor 3,85 dengan kriteria sangat baik, aspek 2) pelaksanaan pembelajaran memperoleh skor 3,91 dengan kriteria sangat baik, dan aspek 3) aktifitas siwa dalam pembelajaran memperoleh skor 3,89 dengan kriteria sangat baik. Secara keseluruhan menurut pengamat pembelajaran kebencanaan berlangsung sangat baik. 


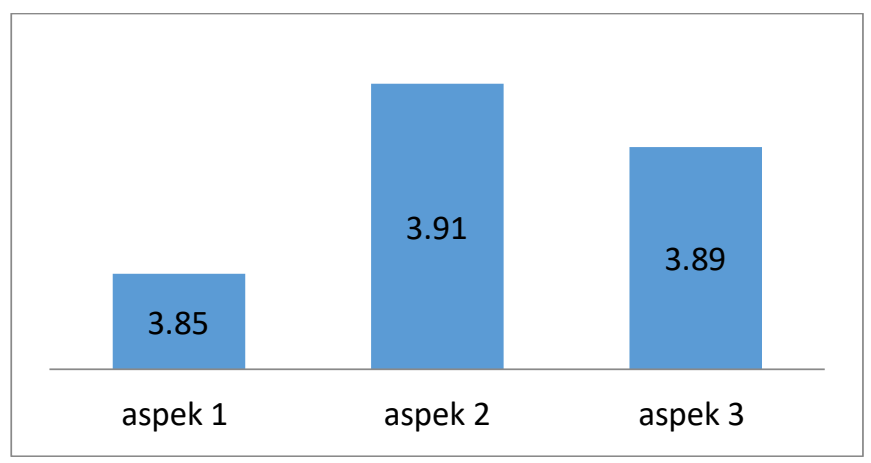

Gambar 7 : Penilaian Observer Terhadap Proses Pembelajaran

Berdasarkan data hasil belajar kesadaran bencana dan peningkatan skor hasil belajar tergambar bahwa pembelajaran dengan alat peraga kotak mitigasi bencana mempengaruhi kesadaran bencana siswa.

\section{KESIMPULAN}

Pengembangan alat peraga kotak mitigasi bencana dapat meningkatkan kesadaran bencana siswa SD Negeri 6 Mataram. Hasil ini didukung oleh respon baik (senang) dari siswa dan proses pembelajaran berlangsung sangat baik.

\section{SARAN}

Berdasarkan hasil penelitian ini, maka tim merekomendasikan pembelajaran kebencanaan sebaiknya menggunakan alat peraga kotak mitigasi bencana sehingga dapat meningkatkan kesadaran bencana siswa.

\section{UCAPAN TERIMA KASIH}

Terima kasih tim ucapkan kepada LPPM Universitas Mataram yang sudah memberikan kemudahan dan fasilitas kepada tim selama proses penelitian berlangsung. Ucapan terima kasih juga tim sampaikan kepada kepala sekolah SD Negeri 6 Mataram, guru dan siswa yang sudah terlibat aktif dalam penelitian ini. Akhirnya, semoga penelitian ini bermanfaat bagi masyarakat sekolah dan lainnya.

\section{DAFTAR PUSTAKA}

Astra, I.M. (2012). Aplikasi Mobile Learning Fisika dengan Menggunakan Adope Flash sebagai Media Pembelajaran. Jurnal Pendidikan dan Kebudayaan, 18(2), 56-65.

Disaptono, S. (2005). Tsunami Mitigation Technology. Jakarta: Republic of Indonesia Maritime and Fisheries Agency Tsunami Mitigation Training Material.

Djamarah. (2005). Teachers and Students in Educative Interaction, A Psychological Theoretical Approach. Jakarta: Rineka Cipta.

Evawani, T., Rahayu, E.S. \& Retnoningsih, A. (2013). Pengembangan Perangkat Pembelajaran Bermakna Menggunakan Lembar Kerja Siswa Divergen pada Materi Ciri-Ciri Makhluk Hidup. Journal of Educational Research and Evaluation, 4(3), 8695.

Jufri, A.W., (2013). Belajar dan Pembelajaran Sains. Bandung : Pustaka Reka Ciptakan 
Kholifudin, M.Y. (2012). Pembelajaran Fisika dengan Inkuiri Terbimbing Melalui Metode Eksperimen dan Demontrasi Ditinjau dari Gaya Belajar Siswa. Prosiding Pertemuan Ilmiah XXVI HFI Jateng \& DIY, Purworejo 14 April 2012. ISSN : 0853-0823

Sutopo, Hadi. (2009). Pengembangan Model Pembelajaran Pembuatan Aplikasi Multimedia Khususnya Puzzle Game pada Mata Kuliah Multimedia. Disertasi. Universitas Negeri Jakarta.

Syahrial, A., Kosim, Gunada. (2019). Bencana Alam Tsunami. Mataram: Duta Pustaka Ilmu.

Syahrial, A. (2019). Tanggapan Guru dan Peserta Didik terhadap Implementasi Pembelajaran IPA (Fisika) SD dengan Kit Alternatif. Jurnal Kappa Program Studi Pendidikan Fisika Universitas Hamzanwadi, 3(2), 89-98.

Syahrial, A. (2019). Model Pembelajaran Kesiapsiagaan Gempabumi di Sekolah Dasar. Jurnal Orbita Universitas Muhammadyah Mataram, 5(2), 65-72.

Sarwi\&Khanafiyah. (2010). Pengembangan Keterampilan Kerja Ilmiah Mahasiswa Calon Guru Fisika Melalui Eksperimen Gelombang Open Inquiry. Jurnal Pendidikan Fisika Indonesia, 6(2010), 115-122.

Wulandari. (2014). Pengaruh Model Pembelajaran Inkuiri Terbimbing terhadap Hasil Belajar Siswa SMA N 1 Pasuruan. Tesis. Universitas Negeri Malang. 